\title{
The Gold Metallurgy of Isaac Newton
}

\author{
E. G. V. Newman
}

The Royal Mint, London

\begin{abstract}
The science of metals had always appealed to Isaac Newton and when, after the conclusion of his remarkable contributions to mathematics and physics, he was invited to take charge of the Royal Mint in London he was able not only to display his great gifts as an administrator but also to exercise his interest in metals and alloys and particularly in the metallurgy of gold.
\end{abstract}

For over thirty years Isaac Newton lived the secluded life of a scholar. As undergraduate and later Fellow and Professor at Cambridge he was shy and reserved, careless of his appearance and even more careless of his eating habits. This period came to a triumphant conclusion, of course, with the publication of the Principia in 1687.

For a further period of thirty years, apparently by an astonishing transformation, Newton served his country as a highly able public official and also as the leader of the scientific community. The achievements and the glory of the former period have not unnaturally overshadowed the latter half of his working life, but it was in this later period, first as Warden and then as Master of the Royal Mint, that Newton became involved with the metallurgy of gold and with the technical aspects of the coinage.

In between these two phases there were a few very unhappy years. His intense labours had brought on a state of mental exhaustion; his election as Member of Parliament for the University of Cambridge from 1689 to 1690 gave him no pleasure; the death of his mother a little later depressed him still further, while his poverty added to the despair he felt that at an age approaching fifty no practical recognition had

\section{Sir Isaac Newton \\ 1642-1727}

Newton's great seientific achievements were all completed at a comparatively early age. He spent the latter half of his working life at the Royal Mint as a suecessful administrator, gradually establishing the reputation for great accuracy and precision that is still characteristic of this institution. During this latter period he also served as President of the Royal Society. In 1705 he was knighted by Queen Anne and became the first scientist to be honoured in this way

From the portrait painted in 1702 by Sir Godfrey Kneller, now in the National Portrait Gallery, London been accorded him for his scientific work despite the endeavours of his friends Samuel Pepys, John Locke and Christopher Wren to secure for him a public post worthy of his stature. He returned to Cambridge and there busied himself with experimental work in chemistry and metallurgy.

It was not until 1696 that an easement came about in the form of an appointment that was to effect a complete change in his way of life and his financial welfare. This came through the good offices of an old friend from his undergraduate days at Trinity College whom he had re-encountered as a fellow Member of Parliament, Charles Montagu. In 1694 Montagu, a skilful politician of strong financial opinions (and virtually the founder of the Bank of England) had been appointed Chancellor of the Exchequer. At this time inflation and the devalued

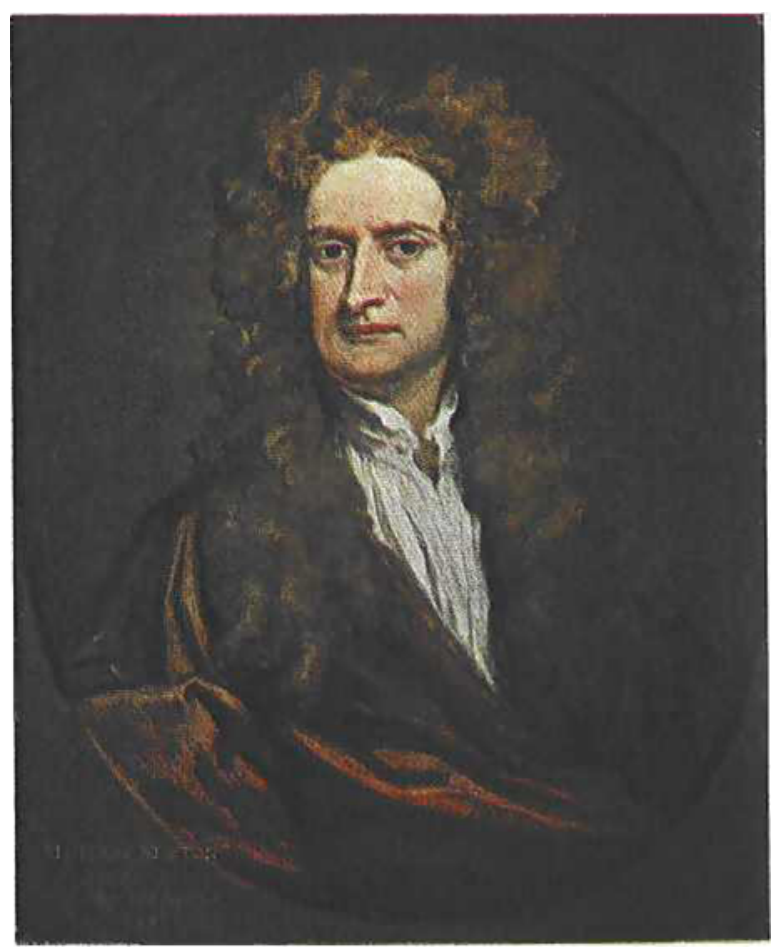


and debased state of the currency were facing William of Orange and his Parliament with grave problems, and in the following year Montagu pushed through the House of Commons a bill for a recoinage of old silver at the then existing standard. This was not only at an immense cost to the country but also involved the Mint in an enormous amount of work, and Montagu looked around for a man of undoubted integrity to supervise affairs at the Mint. On March 19th, 1696 he wrote to Newton:

Sir,-I am very glad that at last I can give you a good proof of my friendship, and the esteem the king has of your merits. Mr Overton, the Warden of the Mint, is made one of the Commissioners of the Customs, and the king has promised me to make $\mathrm{Mr}$ Newton Warden of the Mint. The office is the most proper for you. 'Tis the chief officer in the Mint. 'Tis worth five or six hundred pounds per annum, and has not too much business to require more attendance than you may spare. I desire you will come up as soon as you can, and I will take care of your warrant in the meantime. ...

Let me see you as soon as you come to town, that I may carry you to kiss the king's hand. I believe you may have a lodging near me-I am, Sir, your most obedient servant,

\section{CHAS. MONTAGU}

Newton was quick to accept the post, although the salary turned out to be no more than $£ 400$ a year and for a time he retained the emoluments of his Fellowship at Cambridge and his chair as Lucasian Professor of Mathematics.

Previous Wardens of the Mint had treated their appointments as a sinecure, but Newton immediately devoted his energies to the work and by the following June had drafted a long memorandum to the Treasury setting out in some detail the state of the Mint and recommending an increase in the authority of the Warden-or rather a return to the authority the post formerly carried.

\section{Production Methods at the Mint}

The Mint, already in full production on the recoinage, was then situated, as it had been since the year 1300, in the Tower of London, and although machinery was installed in 1662 and 1663 under Charles II the methods of operation were somewhat primitive. Charcoal furnaces and small earthenware pots were used to melt the gold, which was ladled into sand moulds to yield bars of the width and only a little more than the thickness of the eventual coins. These bars or fillets were then passed, after cleaning, only three times through small rolls turned by horses in the cellar below. Blanks were cut from these strips in a small fly press, these were edge-marked, annealed, cleaned and passed to hand-operated screw presses for coining.

The organisation of these processes was not however as straightforward as modern management would

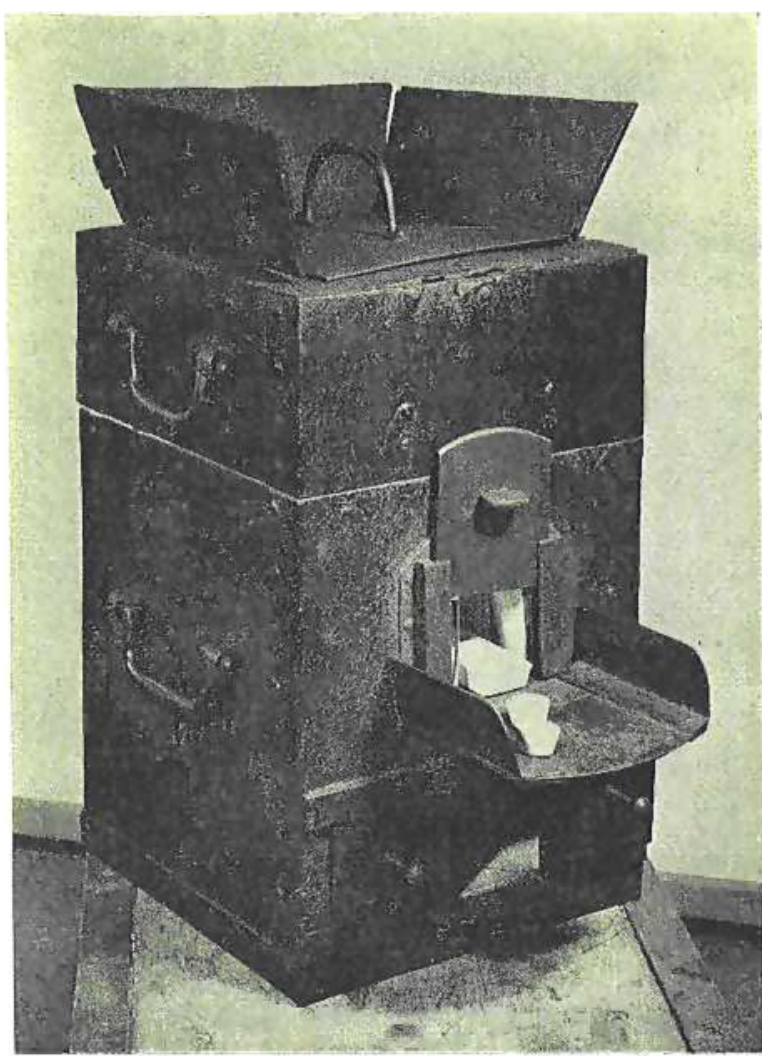

During his long tenure of office at the Mint, Newton carried out many assays of gold coinage himself, and the iron muffle furnace he used is still preserved and is now in the care of the Birmingham Assay Office

conceive, but was split between a number of officials. The Master of the Mint sub-contracted the melting and casting to anyone he chose at whatever price he could obtain; the conversion of the bars into coin he was bound to place with the Company of Moneyers at a price fixed by long usage. These latter hired their own labour and supplied their own tools, the Mint providing only initial capital equipment. The suitability of the melters' bars was checked by the King's Assay Master, an independent official.

In the year following his appointment as Warden Newton compiled a summary of all these operations, including the speed of melting, the speeds of the various types of machines, the number of workmen required for each, and the technique of assaying both gold and silver. He quickly mastered the skills of the assayer and frequently practised them on old coins. (His assay muffle is still preserved.)

The alloy used for coinage was-and of course still is -22 carat gold, that is 916.6 parts per 1000 of gold, the balance then being silver and copper, with a "remedy", or in modern terms a tolerance, of 3.5 parts per 1000 . This matter of the "remedy" was to be one of Newton's major problems in the years to come. 
In 1699 "Thomas Neale, the Master of the Mint, died, and within a few days Newton was appointed to succeed him in the more senior post, undoubtedly on account of his reputation and energetic performance of his duties as Warden, as promotion to Master from within the Mint was most unusual. He continued to occupy this position for the remainder of his life, a period of twenty-seven years. He at once embarked on an administrative reorganisation, but perhaps more significant in the present context he was now in a position to exercise more fully his interest in metals and alloys; in his capacity of Warden much time was devoted to the tracking down and prosecution of counterfeiters, this being the chief duty of the post other than sharing the general overseeing of Mint matters with the other senior officers.

\section{Early Interest in Metallurgy}

Metallurgy had always been among Newton's major interests. Even as a boy of 14 or 15 he recorded in his notebark a recipe for melting:

TO MELT METTLE QUICKLY YEA IN A SHEL

Make a bed or laying of metle, and on it make a other bed $w^{\text {th }}$ powder of brimstone salt peeter $\&$ sawdust. \& like quantitie of either then put a fire to $y^{\mathrm{e}}$ said powder $w^{\text {th }}$ a burning charcole $\&$ it will bee in a mass.

At the age of 23 he wrote to his friend Francis Aston, then about to undertake a journey in Germany and Holland, asking him to observe the extraction of metals from their ores and the processes for refining them, and enquiring about a method said to be used in Germany for obtaining gold from rivers by laying mercury in the stream and then straining the mercury through leather to leave the gold behind.

In the early 1670 s he was busy constructing his reflecting telescope and was much concerned to find a suitable alloy for the mirror, one that would be hard enough to takke a good polish but would not be too brittle. He sxattled on an alloy of 12 parts of copper, 4 parts of tin and 1 of arsenic. A full account of the melting and casting of this alloy and of its polishing is given in a manuscript entitled De Metallo ad Conficiendum Speculum Componendo et Fundendo.

Even during the four intense years when the Principia was being written, 1683 to 1687 , Newton still carried on with chemical and metallurgical experiments. His relative and assistant at this period, Humphrey Newton, has recorded:

About 6 weeks at spring, and 6 at the fall, the fire in the elaboratory scarcely went out, which was well furnished with chymical materials as bodyes, receivers, heads, crucibles, etc., which was made very little use of, the crucibles excepted, in which he fused his metals; he would sometimes, tho' very seldom, look into an old mouldy book which lay in his elaboratory, I think it was titled Agricola de Metallis, the transmuting of metals being his chief design, for which purpose antimony was a great ingredient.

Whether or not Newton was in fact interested in alchemy and the transmutation of metals has been greatly debated over the years, but the use of Agricola's De Re Metallica as a reference book would surely tend to show that he was genuinely concerned with practical metallurgy.

Later, in his depressed period, he still engaged in investigations of this kind, and in a paper read to the Royal Society in 1701, but almost certainly compiled in 1692 or 1693, he not only set out a proposed scale of temperature but also put forward his well known law of cooling and discovered that while a body is melting or evaporating its temperature remains constant.

Thus Newton brought to the work of the Mint at least some understanding of the metallurgy of his day, and although he did not engage in practical work during his long period there ("I employ a melter to melt; I do not make up the charge myself", he once wrote) he was able to bring his great mind to bear on several problems that arose in this field.

The transformation was almost complete. Newton was now comparatively wealthy, he lived in some style, entertained his friends and became part of the social scene, as well as a national figure. In 1672, shortly after he had demonstrated his reflecting telescope, he had been admitted a Fellow of the Royal Society, and in 1703 he was elected President, an office he also retained until his death. In this capacity he became well known to Queen Anne's consort Prince George of Denmark, himself interested in furthering scientific studies, and in 1705 the Queen, on a visit to Cambridge, conferred the honour of knighthood upon him.

Newton's first concern on becoming Master was to set about restoring the accuracy of coining practice that had tended to fall off under his predecessors. Money had been coined unequally, some pieces being too light and some too heavy, with the result that astute refiners and bankers sorted out the heavy ones and returned them to the Mint for recoining, receiving the same weight of coins in return but of course an appreciable gain in monetary value. Newton insisted upon coins being struck as closely as possible to their prescribed or standard weight, a practice that has of course been retained to this day.

\section{The Trial of the Pyx}

In 1701 Newton had for the first time to face the Trial of the Pyx, a ceremonial held under Royal authority involving the assaying of specimens from recent coinage by comparison with standard trial plates carefully prepared to be of the exact composition specified by law. This trial is conducted by a jury selected by the Worshipful Company of Gold- 


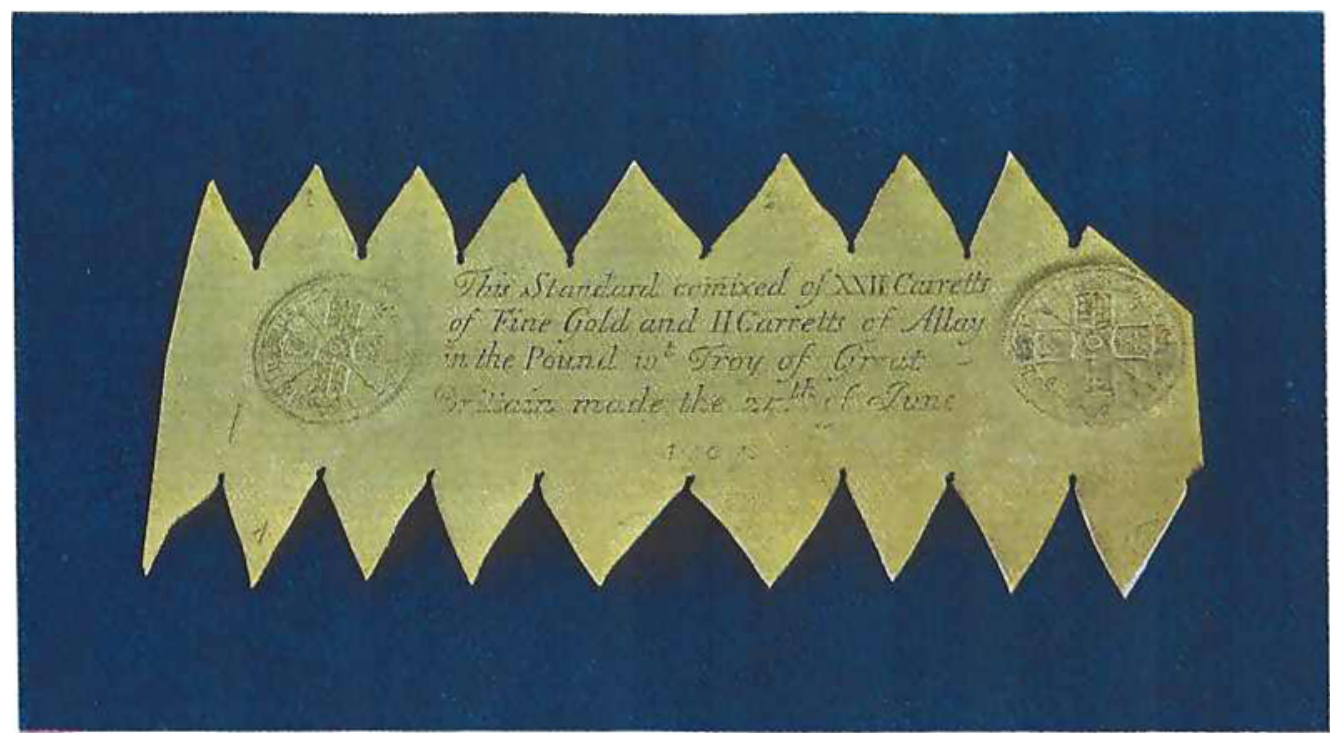

The gold trial plate of 1707. This was used in the Trial of the Pyx in 1710, when the Jury insisted, to Newton's intense annoyance, in rejecting the coin as just over 1 part per 1000 below standard. He maintained that the gold used in making the plate had been refined to a greater purity than before and as a result of his protests the plate was never again used in a trial

smiths, which is also responsible from time to time for the melting, casting and assaying of the trial plates. In 1701 all was apparently in order, but this was by no means the case a few years later. In 1707, Scotland became united with England and the Act of Union called, among other provisions, for the continuance of the Edinburgh Mint but for its bringing into line with the Tower and for the recoinage of the Scottish silver to the English standard. Newton at once sent instructions on melting and casting practice and arranged for representatives from London to spend some time in the Edinburgh Mint to oversee these operations, while the Goldsmiths' Company proceeded to the preparation of new trial plates under a warrant from the Lord High Treasurer, Sidney Godolphin. The records of the Goldsmiths' Company go on to describe how

"the Jury agreed with Mr Cartlitch, Refiner, to prepare them a sufficient quantity of fine gold and silver and so adjourned to meet at Goldsmiths Hall where they made several assays and tryalls of the fine gold and silver and having approved thereof they afterwards went to Mr Cartlitch's house in Oat Lane and there melted down and alloyed the same and on the 11 th, 13 th, 18 th and 21 st of June they proceeded in the work by making several assays and trial of both gold and silver and afterwards in forging out, planishing and indenting the same."

In fact no gold was recoined in Edinburgh, but in 1710 this new trial plate was used for the trial of the English gold coin. Now this John Cartlitch, a Staffordshire man who had been apprenticed to the famous refiner Peter Floyer, appears to have played a double role (not uncommon at this time) as both an independent refiner and Deputy Assayer to the Mint, and he had succeeded in achieving an unusually high degree of purity in his gold. Despite the "several assays and trials" made by the Jury in 1707, the plate was therefore of slightly higher fineness than standard, and to Newton's intense annoyance his coins were adjudged by the 1710 Jury to be defective by 1 part per 1000 although everyone seems to have been aware of what had happened. The Mint officials, including Sir Isaac himself, were so vociferous in their protests that they were virtually thrown out of the Hall by the Goldsmiths.

Newton's annoyance took the form of making repeated assays of his own, followed up by a number of impassioned memoranda, still preserved among a great mass of his manuscripts in the Public Record Office, in which he severely took to task not only the jury but refiners and assayers in general. For example:

"Refiners find it difficult to refine gold to the degree of 24 carats. They seldom make it above 23 carats 4 grains and three quarters of a grain fine, and by fine gold understand gold of this Degree of fineness. And if gold at any time prove finer upon the Assay, Assayers out of prejudice do not report it finer.

"And thence it comes to pass that the goldsmiths are generally of opinion that gold cannot be made above 24 carats fine. But if when they have washed their granulated gold once or twice with Aqua Fortis, they should dulcify it and grind it very fine as painters do their colours, and then dry it and water it once or twice more with double Aqua Fortis in the same degree of heat as before and keep it longer in the water than before, stirring it now and then with a wooden stick to make the gold mix with the fresh water, the gold will become finer than by the assay and by consequence finer than four and twenty carats. Chymists also tell us that Gold may 


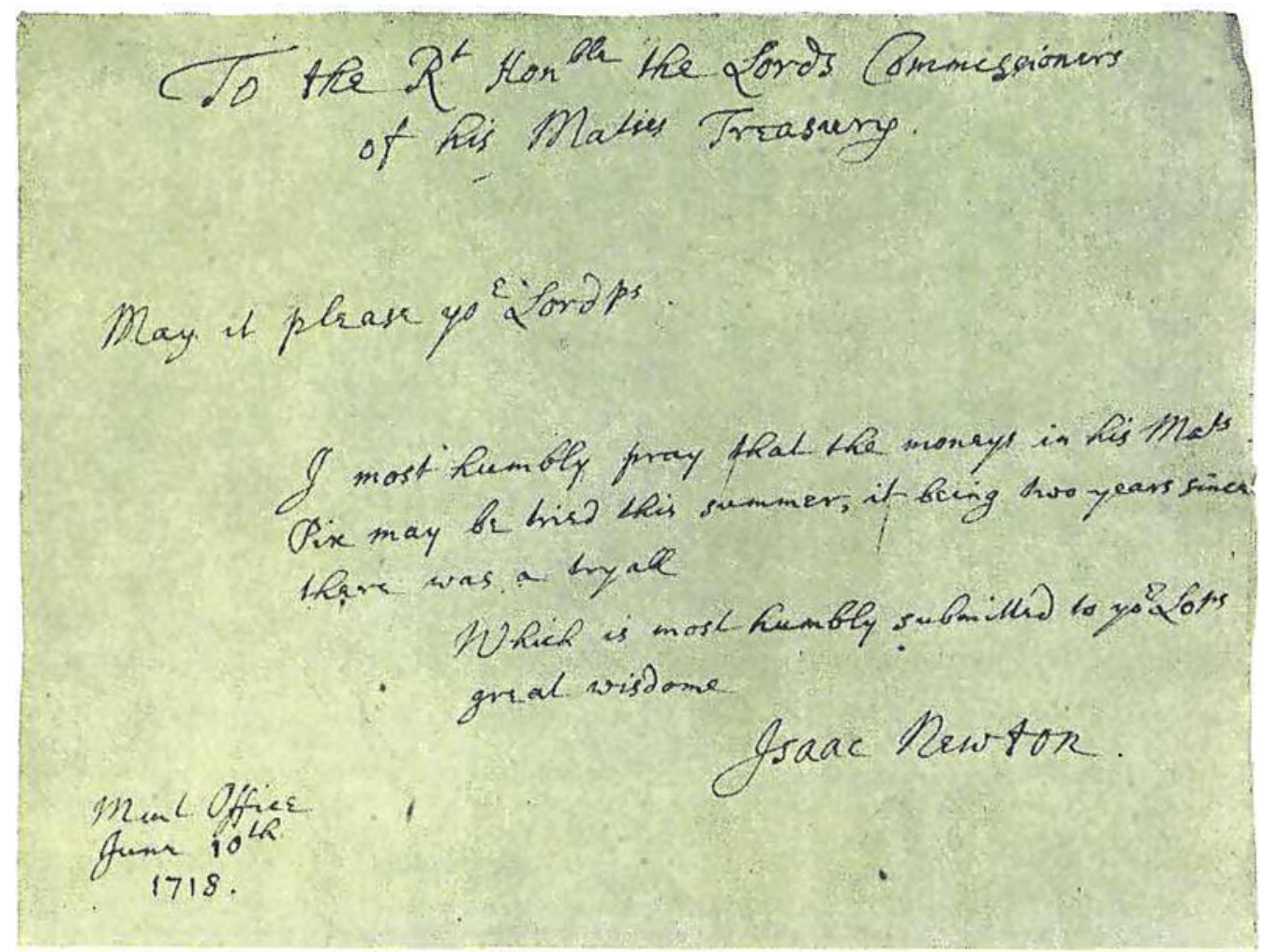

A letter from Sir Isaac Newton to the Lords Commissioners of the Treasury requesting a further Trial of the Pyx in 1718. This is now preserved in the Public Record Office

Crown copyright

be made finer by Antimony than by Aqua Fortis and by consequence than by the Assay; and Gold refined by Antimony is of a better colour.

"If Refiners should work perfectly in the same manner with Assayers, that is, if they should mix gold with silver in the same proportion, and drive it off the Test with ye same proportion of lead and hammer it to ye very same thinness and water it with waters of the same strength in the same degree of heat during the same length of time; their gold would become just 24 carats fine. But they work not with so much curiosity and eagerness."

Whether John Cartlitch used the method involving antimony sulphide to attain a higher purity than was normally achieved by the nitric acid process we shall never know, nor how many times he washed it with nitric acid, but assuredly he had achieved something a little better than ever before in the way of purity in attempting to serve his two masters. A little mystery also surrounds the actual making of the trial plate; Newton wrote:

"The Jury did not themselves refine the Gold and Silver but bought it of my Deputy Mr Cartlich. They know not how he refined them, and wondered that he could make them so fine. But being generally of opinion that no gold or silver could be too fine they made the trial pieces thereof for the money but absolutely refused to give receipts for making their plates thereby."

With his own hands Newton redetermined the assays of the 1707 plate and also those made in 1660 and 1688. The new plate, he reported, "by many assays very carefully made is $\frac{5}{12}$ grain better than standard", while the 1688 plate was $\frac{1}{6}$ grain above standard and the 1660 plate exactly to the standard fineness of 916.6. Newton's protests and the honour of the Mint were upheld, and in the event the 1707 plate was never again used in a trial, the 1688 plate being used until early in the nineteenth century.

In another memorandum, Newton expounded the many ways in which he considered assayers might fall into error:

"And there are other ways of erring as by assaying after any unusual manner, or by scattering any part of the alloy or of the gold or suffering a sensible quantity of the alloy to evaporate or not mixing the gold with the alloy very well, or using a faulty crucible."

It is of course well appreciated nowadays that gold alloys of this type, whether with copper or with silver, are prone to segregation, and it is more than likely that the much abused trial plate of 1707 was not entirely homogeneous.

More recent determinations have in fact shown that Newton's assays were not as accurate as he claimed. In 1873 the then chemist to the Mint, W. Chandler Roberts (later known as Sir William RobertsAusten) carefully re-assayed a number of trial plates and obtained results appreciably lower than Newton's. 
For the purpose of this article the 1688 and the 1707 plates have again been assayed by the kindness of $\mathrm{Mr}$ J. S. Forbes and Mr D. B. Dalladay of the Assay Office at Goldsmitbs' Hall. In this latter case samples were taken from opposite ends of the remaining pieces of the trial plates and the determinations are considered to be accurate to \pm 0.1 part per thousand. The complete results are given in the table, and it will be seen that the 1707 plate was in fact only very slightly above standard fineness, while the 1688 plate was appreciably below. A constant error appears to have been present in Newton's method of assay, probably due to a small amount of silver remaining with the gold.

\begin{tabular}{|c|c|c|}
\hline $\begin{array}{r}\text { Determinations of } \\
\text { and } 17\end{array}$ & $\begin{array}{l}\text { neness } \\
1 \text { Plates }\end{array}$ & 1688 \\
\hline (Nomina & ss 916.6 & \\
\hline & 1688 & 1707 \\
\hline $\begin{array}{l}\text { Issac Newton } \\
\quad(1710)\end{array}$ & 918.4 & 921.0 \\
\hline $\begin{array}{l}\text { Roberts-Austen } \\
\quad(1873)\end{array}$ & 914.6 & 917.1 \\
\hline $\begin{array}{l}\text { Forbes and Dalladay } \\
(1974)\end{array}$ & $\begin{array}{l}914.2 \\
914.5\end{array}$ & $\begin{array}{l}916.8 \\
916.9\end{array}$ \\
\hline
\end{tabular}

Arising from all this embarrassing dispute, Newton also drafted some comments, or rather queries, including this one:

"Whether Her Majesty may appoint trial pieces to be made of such fine gold as proves just 24 carats fine upon the assay and of such fine silver as proves just 12 ounces fine upon the assay notwithstanding that gold or silver may by any new art be refined to an higher degree ?"

This suggestion, of trying the coins against fine gold instead of against an alloyed trial piece, obviously had a great deal of merit, but it was not put into practice until 150 years later!
Newton's main contribution to the nation's money lay perhaps not so greatly in the truly metallurgical sphere but more in his complete integrity and in his insistence upon precision and consistency in its production. But his understanding of the metallurgy of his time was remarkable, and his views were undoubtedly valued by his associates and staff. Many years later, and within six months of Newton's death at the age of 84, the King's Assay Master (George I having succeeded Queen Anne) sought his advice for the last time. This was Hopton Haynes, an old servant of the Mint whom Newton had appointed twenty-five years ago, and he was faced with a problem of whether or not to accept some suspect gold ingots from the South Sea Company. He wrote appealing to the Master to visit the Mint and advise him:

"I have taken all the Care I could, examining what has already been assayed, at ye cutting, hammering, sheering, appearance on the copples [cupels] and after nealling; but propose that the Suspected Ingots be broke in Your presence, the company's Refiner and Agent attending and also ye Melter, when we may be better assured of the Nature of the Mass by a careful inspection of the breakes than we can be by an Assay taken off at one Corner.

"If you please to appoint tomorrow, being Wednesday, or Thursday morning, I will attend in my place.

I am, Honoured Sir Yr most obed ${ }^{\mathrm{t}}$ Servant

Tuesday 6 Sept, 1726 H. Haynes."

By comparison with earlier incumbents of the post, Newton stood head and shoulders above them. $\mathrm{He}$ did not, as had so often been the case, treat the office as a sinecure, but rather regarded it as a job to be done and to be well done. He was not perhaps concerned with innovations or new developments, but in accepting the procedures of his time he used his metallurgical knowledge to ensure that they were carried out properly and exactly.

COLD is a Metallick Body, Citrine, ponderous, mute, fulgid, equally digested Fin the Bowels of the Earth, and very long washed with Mineral Water; under the Hammer extensible, fusible, and sustaining the Tryal of the Cupel, and Cement. . . . And that it hath a fixed Substance void of all burning Sulphureity, is evident by every Operation of it in Fire: for it is neither diminished nor inflamed.

From the translation

ABU JABIR IBN HAYYAN (Geber)

by Richard Russell,

The Sum of Perfection

London, 1678

Baghdad, c. 800 A.D. 